\title{
DEMONSTRAÇÃO DO VALOR ADICIONADO: UM ESTUDO EXPLORATÓRIO, SUA IMPORTÂNCIA COMO FERRAMENTA GERENCIAL NA TOMADA DE DECISÃO NO CONTEXTO EMPRESARIAL
}

\author{
Congresso Nacional Online de Empreendedorismo, 3a edição, de 06/12/2021 a 08/12/2021 \\ ISBN dos Anais: 978-65-81152-30-7
}

COSTA; Renan da Silva ${ }^{1}$, ORTELAN; André Junior Santi ${ }^{2}$, ORTELAN; Juliana Bezerra dos Santos ${ }^{3}$, SILVA; Sidiany Rosa da 4, EDUARDO; Antônio Sérgio 5

\section{RESUMO}

Dentre os grandes desafios levantados pela contabilidade, a identificação, os registros dos fatos ocorridos dentro de uma entidade, certamente a transparência das informações geradas é o mais importante. Segundo Breda (2020) no contexto mundial há uma reivindicação para que as empresas demonstrem a criação de valor, os impactos dos seus negócios e investimentos sobre a sustentabilidade ambiental, social e de governança corporativa, conhecidos pela sigla "ESG" Environmental, Social and Governance, traduzido em português como "ambiental, social e governança". Forma da empresa demonstrar à sociedade que através do seu negócio, que respeitam o meio ambiente, as pessoas e tem uma boa gestão. A busca por relatórios e demonstrações que ajudem os gestores a mensurar a lucratividade, evolução e contribuição econômica das entidades, levou ao surgimento da Demonstração de Valor Adicionado (DVA). Regulamentada pela Lei n. 11.638/2007, tem o propósito de evidenciar a formação e distribuição da riqueza das entidades. Porém, observa-se uma dificuldade na compreensão e utilização dessa demonstração em sua totalidade, visto que, a não obrigatoriedade e bem como a grande parte das empresas, principalmente micro e pequenas, desconhecem sua utilidade e, de certa forma, ignoram seu uso. Este trabalho objetiva evidenciar a importância da DVA como ferramenta gerencial na tomada de decisão pelos gestores e sua relevância como instrumento informativo da riqueza gerada e distribuída pelas organizações de pequeno porte. Utilizando de procedimentos técnicos como estudo de caso, este trabalho classifica-se como estudo de natureza descritiva. As informações de pesquisa foram extraídas de uma empresa de pequeno porte do ramo de comércio e serviços, estabelecida no município de Nova Andradina, estado de Mato Grosso do Sul. Através de informações contábeis fornecidas, foi possível elaborar a DVA e identificar sua importância como ferramenta gerencial na tomada de decisão pela empresa e a distribuição de sua riqueza gerada

PALAVRAS-CHAVE: Demonstrações Contábeis, Tomada de Decisão, Valor Adicionado, ferramenta gerencia 